\title{
From the Olympic dream to a down to earth approach: Lausanne's sports events hosting strategy
}

\author{
Joël Pinson \\ Swiss Graduate School of Public Administration (IDHEAP), University of Lausanne, Lausanne, \\ Switzerland \\ Joel.Pinson@unil.ch
}

The Version of Record of this manuscript has been published and is available in SPORT IN SOCIETY, November 2015, http://www.tandfonline.com, DOI: 10.1080/17430437.2015.1108650

To cite this article: Joël Pinson (2015). From the Olympic dream to a down to earth approach: Lausanne's sports events hosting strategy. Sport in Society. DOI: 10.1080/17430437.2015.1108650.

\begin{abstract}
In the context of globalized competition among territories, cities, regions and countries have to find new ways to be attractive to companies, investors, tourists and residents. In that perspective, major sports events (such as the Olympic Games or the FIFA World Cup) are often seen as a lever for territorial development. Based on that idea, many sports events hosting strategies have emerged in the 1980s and 1990s. However, the growing competition in the sports events' market and the gigantism of those major events, forced some territories to turn to smaller events. This necessary resize of their strategy raises the question of their capacity to meet the initial objectives, which aim usually at developing the economy and promoting the image of the host destination. This essay sketches out the evolution of a sports events hosting strategy in a city that does not have the resources (either financial, human or in terms of infrastructures) to attract major international sports events. The challenges they have to face and a possible solution based on the event portfolio perspective are discussed through the article.
\end{abstract}

\section{Introduction}

A century ago (1915), Baron Pierre de Coubertin established the headquarters of the International Olympic Committee (IOC) in Lausanne. Although, the city never hosted Olympic Games (despite being a candidate five times), Lausanne was designated as the Olympic Capital in 1994 by Juan Antonio Samaranch (president of the IOC from 1980 to 2001). Of course, this title is mostly symbolic and marks the presence of the IOC's headquarters in the city. However, following a time of uncertainty at the IOC due to bribery scandals and a change in the presidency, Lausanne's authorities wanted to institutionalize this situation and its marketing opportunities through a policy: "Lausanne, Olympic Capital" (Municipality of Lausanne, 2002a). This policy has two main targets: international sports federations and organizations (ISFO) and sports events.

Through a proactive strategy, the IOC, Lausanne and the Canton de Vaud attracted in the city, or nearby, 63 headquarters and branches of ISFO, making it de facto the "administrative capital of world sport". The presence of these organizations does not only impact the visibility of Lausanne, the Canton de Vaud and Switzerland, but also have an economic impact for the territory. A recent study made by 
the International Academy of Sports Science and Technology (AISTS, 2015) evaluates that the economic impacts reach on an annual basis over a billion Swiss francs for Switzerland, over half a billion for the Canton de Vaud and a quarter billion for the city of Lausanne. If the public authorities understand the interest for their territory to attract ISFO, the development and the implementation of a hosting strategy were only made possible through collaboration between the IOC, the city and the canton from 2010. This strong partnership can be observed through projects such as "La Maison du Sport International" which offers offices to ISFO not far from the IOC's headquarters. This particular project saw the creation in 2001 of a limited company - Maison du Sport International SA - with the IOC, the Canton de Vaud and the city of Lausanne as equal shareholders. Of course, for the IOC and the local authorities their partnership is a win-win situation. The IOC needed the support of the local authorities to attract these sports organizations and federations in Lausanne (through specific legislations and agreements), while the presence of the IOC played a tremendous part in the attractivity of the territory for ISFO.

Originally, the sports event hosting strategy was influenced by some of the IOC's former presidents. Baron Pierre de Coubertin wanted the Olympic Games to take place in the city to fully integrate Lausanne in the Olympic family. While, a few decades later, Juan Antonio Samaranch wanted sports to live in the Olympic Capital through the organization of sports events (Morath, 2000). If the hosting strategy towards ISFO is easier to assess, through the economic impact and the number of organizations which choose to move their headquarters or offices to Lausanne on a yearly basis, the sports events hosting strategy (SEHS) is more difficult to evaluate. This paper will analyse how Lausanne's SEHS developed over time and how from an IOC's impulsion, it became a public policy and now a public strategy that evolves with the context. Therefore, this paper will first focus on the influence of Baron Pierre de Coubertin and Juan Antonio Samaranch on the sports events that Lausanne wanted to host or hosted. The paper will then explain why the local authorities decided to take over the leadership of this strategy and how it developed. Finally, some of the questions territories engaged in SEHS should answer will be discussed, as well as future challenges for Lausanne's SEHS.

\section{The IOC's influence}

As mentioned before, the IOC through two of its former presidents influenced the perceptions of Lausanne's authorities towards sports events. Baron Pierre de Coubertin strongly influenced Lausanne's authorities' choice to be a candidate city to host the Olympics (Gilléron, 1993). This "Olympic dream", supported at its beginning by Coubertin, will lead to five failures in front of the Olympic Committee (for the Summer Olympic Games of 1936, 1944, 1948, 1952 and 1960) and one failure in a referendum (for the Winter Olympic Games of 1994). After his election as IOC's president, Juan Antonio Samaranch wants Lausanne to be more than the administrative capital of world sport. To this end, he will, along with a network of local public figures, suggest the organization of recurrent sports events and advise Lausanne to host international one-off events (IOOE) (Morath, 2000).

\section{Coubertin and Lausanne's Olympic dream}

At the beginning of the $20^{\text {th }}$ century, Coubertin is thinking about fixing the Olympic Games in one location by creating a "modern Olympia" (Gilléron, 1993). Political tensions throughout the world and difficulties to find host destinations seem to be Coubertin's main motivations behind this project. Morges, a city between Lausanne and Geneva, will be the first location selected. However, after a change in the elected officials, the project falls through. Despite this failure, Coubertin still believes that a modern Olympia is possible. In 1918, a new site is selected and architectural plans are drawn on 
the lake shores nearby Lausanne. This time, the economic situation and the general context following the war do not make the realization of such an important project feasible (Gilléron, 1993). This second failure marks the end of the modern Olympia's dream and the begging of the Lausanne's wish to host the Olympic Games.

As mentioned by Gilléron (1993), it is in 1905 that Coubertin mentioned for the first time the possible organization of the Olympic Games in Lausanne. However, it is only after the modern Olympia's project is dropped, that he will lobby the local authorities to be a candidate city. In 1924, Lausanne will be officially a candidate to host a future Olympic. Lausanne's candidacy is open for the Games of 1932 in replacement of Los Angeles (should they replace Amsterdam for the Games of 1928) or 1936 not yet attributed. It is interesting to note that the local authorities decided to send the official letter of candidacy directly to Coubertin and not to the IOC (Gilléron, 1993). Of course, the candidature process at the time is not as regulated as is it today. However, this clearly shows Coubertin's influence over the decision of the local authorities to be a candidate city. The 1928 Olympics will take place in Amsterdam and those of 1932 in Los Angeles. In 1936, with Berlin as a candidate city, Coubertin advises Lausanne to postpone their candidature for the Games of 1944, which is the year of the fiftieth anniversary of the foundation of the IOC. For Coubertin, this jubilee is a good opportunity for Lausanne to host the Olympic Games. Especially, since the city will host the celebrations of the fiftieth anniversary (Gilléron, 1993). Finally, Lausanne's candidacy for the 1944 Olympics will be unsuccessful (London will be designated, although the 1944 Games will be cancelled due to Second World War), as will the following ones in 1948 and 1952.

All these consecutive failures have two main explanations: Coubertin's loss of influence at the IOC and the change of context for the selection of the host destination. For a long time, Lausanne's authorities believed that Coubertin's wish to see the Olympic Games take place in the city should be enough to win the candidacy. However, after his retirement in 1925, distance grew between him and the new IOC's board. The postponement of the designation of the host city for the 1944 Olympics to the IOC Congress of 1939 and the sudden death of Coubertin in 1937 further sweep away Lausanne's dreams of hosting the Olympics. The second dimension is mostly influenced by the transformation of the Games themselves. Since the 1930s, political stakes behind the selection of the host destination are being more and more evident for the summer Olympic Games. For instance, the 1936 Berlin Olympics are used by Hitler and the Nazi party to promote the "new Germany" (Wamsley, 2002). Furthermore, the growth of size of the Olympics, both in terms of athletes and competitions, requires more infrastructures and, therefore, bigger cities with more resources. Within this context, it is complicated for Lausanne, a city only about 80 '000 inhabitants at that time, to find the right arguments to win the candidacy.

Lausanne will again be a candidate city for the Games of 1960 and 1994. The selection of the host city for the 1960 Olympic Games is the only time Lausanne came close to win the bid. Lausanne was only defeated by Rome on the third round by 11 votes. A few decades later, Lausanne will try to host the 1994 Winter Olympics. But, in 1988, the candidacy is withdrawn after a referendum where $62 \%$ of the local population voted against the financial risks that come with the organization of such an event (ATS, 1988). This result was a surprise, since only the ecologist party was against it. The disapproval of the local population will put an end to Lausanne's desire to host the Games. However, the foundation of the Youth Olympic Games (YOG), held for the first time in Singapore in 2010, is a new opportunity for the city to pursue its Olympic dream. In July 2015, Lausanne and the Canton de Vaud were designated to host the 2020 Winter YOG against Brasov, Romania. 
It is interesting to observe how, from a wish by Baron Pierre de Coubertin to see the Olympic Games take place in Lausanne, this idea evolved overtime from Summer to Winter Olympic Games and now YOG. Of course, this evolution is rational in the perspective of a city that does not have the resources (neither financial nor in terms of infrastructures) to host a mega event such as the Olympics. However, as presented later in this paper, this evolution can also be observed in the SEHS of the city. To face the growing competition in the sports events' market (making it more and more difficult to be designated as a host destination for sports events) and the gigantism of those events, mid-sized cities, such as Lausanne, have to rethink their SEHS. Before looking at it more specifically, we need to focus on the impulsion of Lausanne's SEHS and one of its main promotor: Juan Antonio Samaranch.

\section{Juan Antonio Samaranch's vision for the city}

Although, the relations between the city of Lausanne and Baron Pierre de Coubertin were good (but somehow inconsistent), it is only under Juan Antonio Samaranch that the relation between the IOC and the city will be strengthened (Morath, 2000). After his designation as president, Samaranch wants Lausanne to be the cornerstone of his action for the Olympic movement. Designated as "Olympic City" in 1982, Lausanne receives the title of "Olympic Capital" in 1994 on the hundredth anniversary of the IOC foundation. The extensions of the IOC's headquarters in 1987 and 1998 as well as the opening of the Olympic Museum in 1993 are tangible confirmation of the IOC desires to remain in Lausanne. To strengthen the IOC's influence on world sport, Samaranch also lobbies for other international sports organizations and federations to move to the city. His desire is realized in 1984 when the International Volleyball Federation moves to Lausanne. As mentioned before, today 63 headquarters and branches of ISFO are based in the Canton de Vaud (among which 54 are in Lausanne).

Samaranch does not want Lausanne to be only an administrative capital of world sport. Through the organization of recurrent and one-off events, he wants the city to be seen as a place where sports live. Sports events should also help the local population to identify with the Olympic movement and the future projects they might want to develop. Therefore, along with the local authorities, the IOC suggested and supported the creation of recurrent events such as the "20km de Lausanne" in 1982, the curling competition "la Coupe du président" in 1985 or the swimming competition "la Traversée du Léman" in 1987. Behind these local events, meant to engage with the community, Lausanne starts to be a candidate city to host IOOE. Supported by Juan Antonio Samaranch, Lausanne will win the candidacy to host the World and European championships (WC-EC) in gymnastics (1990 and 1997), figure skating (1992, 1997 and 2002) or curling (1988 and 2001) throughout his presidency. Although, the relations between the city and the IOC were good, questions started to rise whether or not his successor would continue to support this strategy.

\section{Toward a Lausanne's leadership}

The end of the nineties is a time of doubts in the relation between the city of Lausanne and the IOC. The image of the Olympic movement in the eyes of the local population and elsewhere is damaged due to bribery scandals around the designation of Salt Lake City as host city for the 2002 Winter Olympics. Furthermore, the succession of Juan Antonio Samaranch raises some questions. The desire of his successor to keep the headquarters in Lausanne is questioned. Realizing the benefits from the presence of the IOC on its territory, the local authorities integrate in their 1998-2001 legislature programme the promotion of Lausanne as the Olympic Capital (Chappelet, 2006). To that purpose, they create a working group to define the main axes that this promotion strategy should integrate. The organization of sports events (both recurrent and one-off) is one of them, along with the installation of 
international sports organizations' headquarters and offices, the improvement of sports infrastructures and the reinforcement of the relation between the IOC and the local population (Chappelet, 2006).

These thoughts lead in 2002 to the adoption of a new sport policy in Lausanne called "Plan Directeur du Sport" (Municipality of Lausanne, 2002b). This public policy, along with the one mentioned before "Lausanne: Olympic Capital" (Municipality of Lausanne, 2002a), aims at promoting Lausanne internationally by attracting ISFO, major events and, of course, tourists. The branding of Lausanne through sports, and international sports especially, is reinforced in 2006, when a place branding policy is adopted (Municipality of Lausanne, 2006). If the strategic vision behind it is to make Lausanne more attractive to investors, companies, tourists and residents, the only measurable objective is to host one international sports event per year (Pinson \& Chappelet, 2014). As presented in Figure 1, the type of events organized in Lausanne changed overtime. From mostly WC-EC, it moved over the years to IOOE that are not meant to designate a European or World champion. These events are usually not intended to remain in the same city for more than a couple of years (such as the FIBA 3x3 World Tour in Basketball). For instance, in Lausanne they have been cycling tours (Tour de Suisse), Davis Cup or Fed Cup matches in tennis, international sport exhibitions (World Gymnaestrada in gymnastic) or events organized by private companies to promote their products (for instance, the Redbull Crashed Ice). If their size and shape can vary, the aim is still to give an international visibility to the host destination.

Figure 1: International one-off events in Lausanne, 1980-2015 ${ }^{1}$

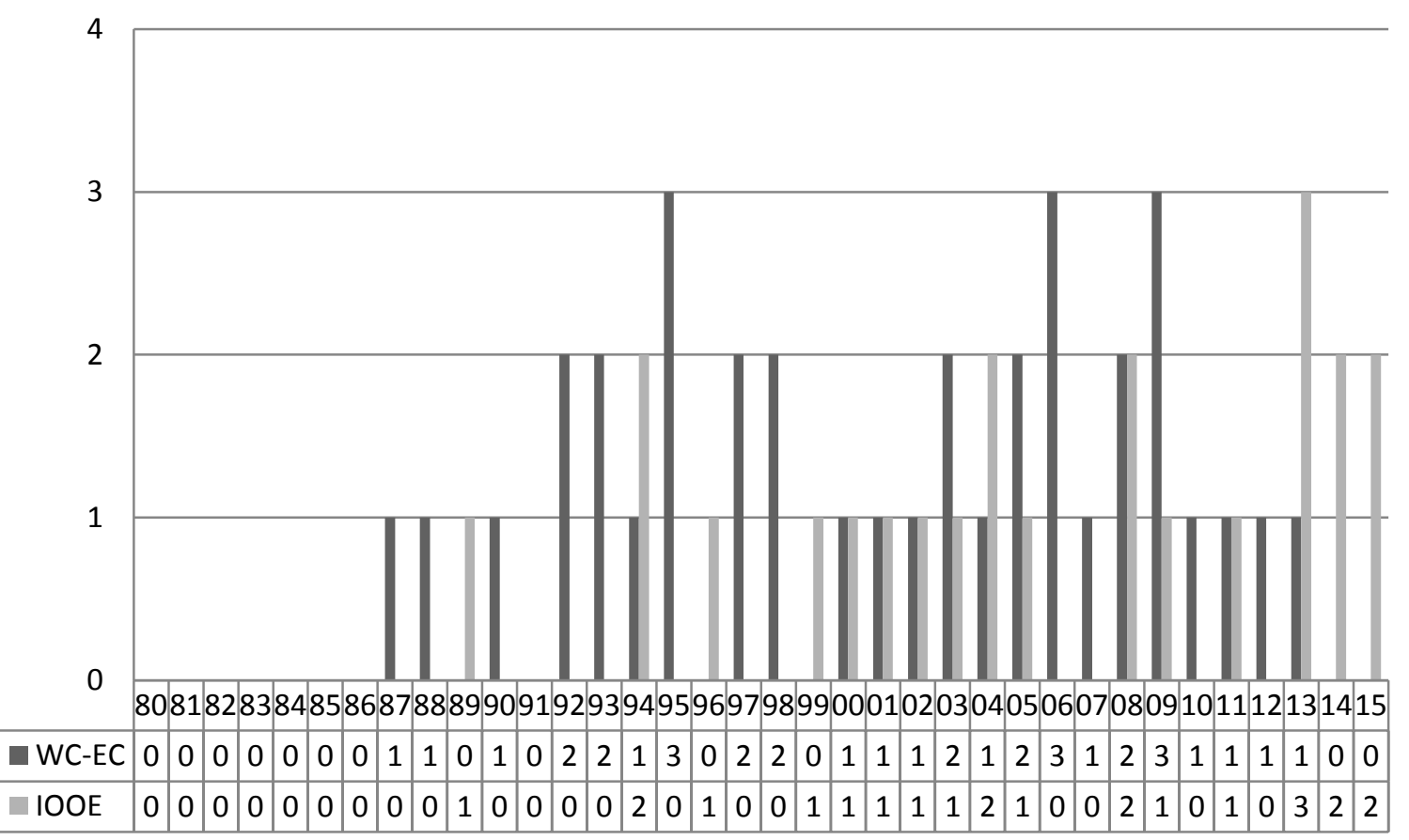

As presented in Figure 1, the type of events hosted by the city of Lausanne evolved from WC-EC to IOOE in the last few years. This can be explained mostly by two factors. Firstly, Juan Antonio Samaranch was proactive in promoting Lausanne's SEHS. He pushed some international sports federations into according the organization of their World or European championships to Lausanne (as for the 1997 World Figure Skating Championships). His successor - Jacques Rogge - did not play such an active role in Lausanne's SEHS. Secondly, but related to this first factor, the competition in the

\footnotetext{
${ }^{1}$ The full list is available from the authors.
} 
sports events' market makes it harder to be designated as host city. The will of the former IOC's president to see international events taking place in Lausanne was of course a competitive advantage for the city in its candidature processes. Without this proactive support, it is harder to be competitive against bigger cities, regions or countries. Furthermore, with the growing size of the events, cities such as Lausanne (340'000 inhabitants with its surroundings) do not have the resources (either financial or in terms of infrastructures) to host World or European championships within the most popular sports. Therefore, they have to turn to second-tier sports events, such as the World Orienteering Championships organized in Lausanne in 2012. If the impacts and the legacy of major events are already questioned (Black et Van der Westhuizen, 2004; Hede, 2005; Feddersen et Maennig, 2012), it is even harder to imagine that one-off events from less popular sports (meaning fewer media coverage and fewer spectators) can contribute significantly to territorial development.

This last comment is important. Given the financial constraints, the public authorities are limited in their capacity to host sports events. Therefore, to maximize the resources they have at their disposal, one could imagine that sports events would be chosen according to a strategy based on clear objectives. Since, these objectives are not clearly exposed in Lausanne's SEHS (Pinson \& Chappelet, 2014), it raises the risk of a poor allocation of resources. Furthermore, the absence of clear objectives behind the hosting strategy makes it more difficult for local authorities to choose the right event to bid for. For instance, if the organization of one particular sports event can be considered as a success by the population or the media (due to sporting accomplishments or the number of spectators), the same event could be considered as a failure in the perspective of the public authorities and their hidden objectives (no extra overnight stays, lack of community involvement, etc.). For that reason, territories engaged in SEHS should reflect on two questions: Why should they host sports events? And, what kind of sports events should they look for? Of course, the answer to the "what kind" question is influenced by the answer to the "why" question.

\section{Why host sports events?}

Originally, the logic behind most of the SEHS is based on attracting exogenous resources (IOOE) to the territory. Influenced by the financial success of the 1984 Los Angeles Olympics, local authorities believed that those IOOE are the best solutions to initiate or/and accentuate local development (Gratton, Dobson \& Shibli, 2000). Although, numerous reasons to host an event can be mentioned, it is usually their expected economic impacts for the territory that are highlighted by the authorities. However, the capacity of sports events to brand and promote the host destination to investors, companies, tourists and residents should not be neglected (Hede, 2005; Mason \& Duquette, 2008; Misener \& Mason, 2008; Fourie \& Santana-Gallego, 2011), as their use for personal ends, especially political purposes (Chappelet, 2006). Since, post-event evaluations are rarely done, and if it is the case mainly for direct economic impacts, all the expected effects remain theoretical. However, if cities from London to Vancouver, regions from Victoria (Australia) to Savoy (France) and countries from Denmark to Qatar are engaging in SEHS, they must have "good" reasons to develop these strategies. One of the major issues comes from the gap between the optimistic forecasts and the actual impacts on the local economy and society (Vigor, Mean \& Tims, 2004). Three main reasons are usually mentioned to support the organization of a major sports event: the stimulation for the local economy, the repositioning of the image and the regeneration opportunities.

For the advocates of SEHS, by working as catalysis for investments, events will stimulate the economy. It should benefit local businesses, while the authorities would see a growth in taxes revenues. Of course, this is a very optimistic vision of the virtuous circle created by hosting sports 
events. Although, the economic impacts are the most common reason mentioned by public authorities to legitimate the organization of sports events, they are also a very delicate dimension to assess and which are often misinterpreted (Barget \& Gouguet, 2011). How can we account the locals who are not attending the event? Should we count a visitor who wished to visit the city anyway, but arranges his trip during the event? And, what about the hidden costs? For instance, Teigland (1999) shows that within five years after the Lillehammer 1994 Winter Olympics, $40 \%$ of the hotels in the regions went bankrupt. It does not mean that sports events cannot have positive economic impacts for the host destination and the local businesses. The advocates will typically emphasize the short-term economic impacts of hosting sports events, especially through outside visitors, while the critics will concentrate on the long-term and the social costs for the local community (Whitson \& Horne, 2006).

The branding opportunities are another reason highlighted by advocates of SEHS. By giving an international visibility to the territory, it should be possible to build a positive image of the city, the region or the country to attract potential investors, companies, tourists and residents (Mason \& Duquette, 2008; Misener \& Mason, 2008; Fourie \& Santana-Gallego, 2011; Vuignier, 2015). As for the economic impacts, this is also a very delicate dimension to assess and few studies have been done to evaluate the results from an event on the image of a territory. Waller, Trendafilova and Daniell (2015) found, in a study on the impact of the World Series (in baseball) on Detroit's image, some mixed evidence about the role of sports events as a vehicle for building a positive image. In their study, if some media and stakeholders are optimistic about the impact on the city's image, they also found that the organization of the event emphasized some issues such as the high crime level in the city or the decline of the automobile industry. Therefore, the organization of the World Series in Detroit also painted a rather gloomy image of the city. Similarly, Zhang and Zhao (2009) found in a study on the 2008 Beijing Olympic Games that, on the one hand, the event raised the city profile as a tourist destination while, on the other hand, issues related to the air pollution were highlighted in international media. As we can see, they are some pros and cons regarding the branding opportunities. It is also interesting to observe that the studies mostly focus on major international events and therefore, on their influence on an international audience. The impacts of recurrent events on the image of a city, as well as the transformation of the image in the residents' perception, are generally neglected.

A third dimension often pointed out is the opportunity through the organization of major sports events to regenerate the city. This regeneration can be multidimensional (physical, economic or social). The physical regeneration tackles run-down buildings and communal areas within the city. The 1992 Olympic Games in Barcelona is a good example of urban regeneration. According to Varley (1992), Barcelona's planners ploughed $83 \%$ of the total expenditure for the 1992 Games into urban improvements rather than into sport. From the extension of the metro system to the creation of flats in the Olympic Village, many urban improvements can be identified. However, the most significant one might be the five kilometres of coastline and new beaches that the public gained access to (Gold \& Gold, 2008). Economic regeneration refers to the aim at creating jobs and wealth through the organization of an event. Sheffield and Manchester can be seen as examples on how cities are using sports for economic regeneration. In both cases, the drivers of such strategies were the loss of their conventional industrial base and the need for new employment opportunities (Gratton, Shibli \& Coleman, 2005). Of course, this goes along with a rebranding of the destination from an industrial city to a tourist destination. Finally, the social regeneration looks at tackling the social problems that lead to deprivation and social exclusion. For instance, Misener and Mason (2008) argue that new social networks are being created through participation, planning, volunteering, and often consumption of sports events. That in turn can help develop communities and social capital. 
Many other reasons could have been mentioned, such as the use of events to develop sport participation within the community or the personal ends discussed earlier. However, throughout this section, sports events were presented as if only one type of sports event existed, that is to say, major sports events. Of course, they come in many shapes and sizes, from regional recurrent events to IOOE. This is an important element to consider. Since, the development purposes of strategies based on hosting sports events are usually multidimensional (economic, social or in terms of image), it is difficult, if not impossible, to find one type of event that will suit all of them. Therefore, cities and regions engaged in a SEHS should reflect on the mix of events they have, or could have, more than on the one-off events they are hosting.

\section{The event portfolio perspective}

From the FIFA World Cup, watched by millions of people around the world, where only professional athletes are competing, to a local running event, where participants have to pay an entry fee, sports events can describe many realities and different typologies have been created to catch this diversity (Ritchie, 1984; Hall, 1989; Jago and Shaw, 1998; Getz, 2008; Chappelet \& Parent, 2015). However, when it comes to development strategies, usually only IOOE are considered. Influenced by the financial success of the 1984 Los Angeles Olympics, the perspective is that those IOOE are the best solutions to initiate or accentuate local development. Due to the focus of local authorities and researchers on the economic and tourism impacts of mega events, it remains unclear whether or not small- and medium-sized events can actually positively impact the territory and the local community (Taks, Chalip \& Green, 2015).

Recent research (Misener \& Mason, 2007; Taks, 2013; Taks, Green, Misener \& Chalip, 2014) suggest that non-mega sports events have a higher potential than mega sports events to grow the social capital of people within the host community. This could affect the overall well-being of the community, especially from a non-monetary perspective (i.e. social regeneration). By having a different target audience (local versus international spectators and participants), non-mega sports event and mega sports events can also have different aims and impacts. Therefore, in terms of territorial strategy, they should be seen as complementary. By planning different type of events (local, international, cultural, sporting, recurrent, one-off, etc.) throughout the year, territories are developing an event portfolio (Ziakas \& Costa, 2011). When strategically planned, this portfolio can lead to a sustainable and multidimensional development of the territory.

As mentioned before, territories engaged in SEHS usually focus on IOOE. However, consciously or not, most of these territories already have an event portfolio with different types and size of events planned through the year, but it is usually not sustained by a strategic vision. In that perspective, the case of Lausanne is interesting. As presented previously, the development strategy based on attracting international sports events to the territory is supported by two policies (Municipality of Lausanne, 2002a and b) and is integrated into the promotion strategy of the city (Municipality of Lausanne, 2006). Recurrent sports events are only mentioned once (Municipality of Lausanne, 2002b) as a potential recipient of subsidies and are not integrated in any promotion strategy. Nonetheless, Table 1 shows that the actual sports events organized in the city are mostly regional recurrent sports events. Of course, this is not surprising since the costs to organize that kinds of event are much lower (both financially and in terms of access to the event). The fact that these events are not integrated in the broader sports event hosting strategy increases the possibility of a poor allocation of resources that might lead in the long-term to the disappearance of some recurrent events that are part of the local identity and that could over time become heritage sporting events (Pinson, 2014). Furthermore, the 
planning of the events through the year is a first step towards the management of an event portfolio. As we can see in Table 1, 78\% of the events are organized between spring and summer in Lausanne. This raises the risk of attracting more people to the city during the tourism pick season, while eventrelated destination marketing strategies usually look at creating new tourism revenues during non-peak periods. However, as presented in Table 1, a balance already exists in Lausanne between participantand spectator-driven events, one-off and recurring events or international and local events. A strategic vision behind the organization of sports events is still missing in Lausanne. It could help planning different types of events, targeting different public and achieving multidimensional development objectives (social, economic and in terms of image) generally expected from a SEHS.

Table 1: Sports Events in Lausanne, 2015

\begin{tabular}{|c|c|c|c|c|c|c|c|}
\hline $\begin{array}{c}\text { Number } \\
\text { of events }\end{array}$ & One-Off & $\begin{array}{c}\text { International } \\
\text { audience }\end{array}$ & $\begin{array}{c}\text { Events in } \\
\text { Spring }\end{array}$ & $\begin{array}{c}\text { Events in } \\
\text { Summer }\end{array}$ & $\begin{array}{c}\text { Events in } \\
\text { Autumn }\end{array}$ & $\begin{array}{c}\text { Events in } \\
\text { Winter }\end{array}$ & $\begin{array}{c}\text { Elite } \\
\text { Events }\end{array}$ \\
\hline 27 & 2 & 3 & 13 & 8 & 4 & 2 & 5 \\
\hline $100 \%$ & $7 \%$ & $11 \%$ & $48 \%$ & $30 \%$ & $15 \%$ & $7 \%$ & $19 \%$ \\
\hline
\end{tabular}

\section{Conclusion}

In 2020, with the organization of the Winter Youth Olympic Game, Lausanne will finally achieve its "Olympic Dream" started with Baron Pierre de Coubertin at the beginning of the $20^{\text {th }}$ century. Despite being a candidate five times, the city never succeeded to host Summer or Winter Olympic Games. With the nomination of Juan Antonio Samaranch as IOC's president, the focus turned from Olympic Games to major IOOE. However, to face the growing competition in the sports events' market (making it more and more difficult to be designated as a host destination for sports events) and the gigantism of those events, Lausanne had to rethink its SEHS. They had to turn to smaller events (but still IOOE) in less popular sports (see Chappelet \& Pinson, 2015). This necessary resize of the strategy raises the question of its capacity to meet the initial objectives, which aim usually at developing the economy and promoting the image of the host destination. As presented, the lack of a clear vision and objectives behind the hosting strategy in Lausanne increases the risk of a poor allocation of resources. Furthermore, the absence of clear objectives behind the hosting strategy makes it more difficult for local authorities to choose the right event to bid for. Therefore, the local authorities need to rethink their development and promotion strategies. To this end, they have to wonder why they want to host sports events and what kind of sports events they should be looking for. As presented in the article, so far, there is an ambiguity between the type of event the city is looking for (major IOOE) and the events that are actually organized on the territory (mostly recurrent local events). In an event portfolio perspective, this is not problematic, since these events have different aims and target audience, it can lead to a sustainable and multidimensional development of the territory. However, a strategic vision with clear objectives still needs to be defined to sustain Lausanne's SEHS. 


\section{References List}

AISTS. 2015. The Economic Impact of International Sports Organisations in Switzerland 2008-2013. Accessed June 4, 2015. http://www.aists.org/ImpactStudy.

ATS. 1988. "JO d'hiver à Lausanne: un non sans équivoque [Winter Olympics in Lausanne: a clear no].” L'Impartial, June 27.

Barget, E., and J.-J. Gouguet. 2011. "De l'importance des dépenses des spectateurs étrangers dans l'impact touristique des grands événements sportifs" [The Importance of Foreign Spectators' Expenses in the Tourist Impact of Major Sports Events]. Téoros, Revue de recherche en tourisme 30 (2): 105-119.

Black, D., and J. Van Der Westhuizen. 2004. "The Allure of Global Games for Semi-peripheral Polities and Spaces: A Research Agenda.” Third World Quarterly 25 (7): 1195-1214.

Chappelet, J.-L., ed. 2006. Les politiques publiques d'accueil d'évènements sportifs [Sports Events Hosting Public Policies]. Paris: L’Harmattan.

Chappelet, J.-L., and M. M. Parent. 2015. "The (Wide) Word of Sports Events." In Handbook of Sports Event Management, edited by M. M. Parent and J.-L. Chappelet, 1-17. London: Routledge.

Chappelet, J.-L., and J. Pinson. 2015. "Évolutions des politiques publiques d'accueil d'événements sportifs." [The Evolution of Sports Events Hosting Public Policies]. Revue européenne de management du sport 45: 8-16.

Feddersen, A., and W. Maennig. 2012. "Sectoral Labour Market Effects of the 2006 FIFA World Cup.” Labour Economics 19 (6): 860-869.

Fourie, J., and M. Santana-Gallego. 2011. "The Impact of Mega-sport Events on Tourist Arrivals." Tourism Management 32 (6): 1364-1370.

Getz, D. 2008. "Event Tourism: Definition, Evolution, and Research.” Tourism Management 29 (3): 403-428.

Gilliéron, C. 1993. Les relations de lausanne et du mouvement olympique à l'époque de Pierre de Coubertin 1894-1939 [The Relations between Lausanne and the Olympic Movement in the Time of Pierre de Coubertin 1894-1939]. Lausanne: Edition CIO.

Gold, J., and M. Gold. 2008. "Olympic Cities: Regeneration, City Rebranding and Changing Urban Agendas." Geography Compass 2 (1): 300-318.

Gratton, C., N. Dobson, and S. Shibli. 2000. "The Economic Importance of Major Sports Events: A Case-study of Six Events." Managing Leisure 5 (1): 17-28.

Gratton, C., S. Shibli, and R. Coleman. 2005. "Sport and Economic Regeneration in Cities." Urban Cities 42 (5-6): 985-999.

Hall, C.-M. 1989. “The Definition and Analysis of Hallmark Tourist Events.” GeoJournal 19 (3): 263268.

Hede, A.-M. 2005. "Sports-events, Tourism and Destination Marketing Strategies: An Australian Case Study of Athens 2004 and Its Media Telecast.” Journal of Sport \& Tourism 10 (3): 187-200.

Jago, L., and R. Shaw. 1998. "Special Events: A Conceptual and Definitional Framework." Festival Management and Event Tourism 5 (1): 21-32. 
Mason, D. S., and G. H. Duquette. 2008. "Urban Regimes and Sport in North American Cities: Seeking Status through Franchises, Events and Facilities." International Journal of Sport Management and Marketing 3 (3): 221-241.

Misener, L., and D. S. Mason. 2008. "Urban Regimes and the Sporting Events Agenda: A CrossNational Comparison of Civic Development Strategies." Journal of Sport Management 22: 603627.

Morath, P. 2000. Le CIO à Lausanne 1939-1999 [The IOC in Lausanne 1939-1999]. Bière: Cabedita.

Municipality of Lausanne. 2002a. Lausanne, Capitale olympique: Demande de crédit-cadre. [Lausanne, Olympic Capital: Application for a Framework Budget]. Lausanne: Préavis. $\mathrm{N}^{\circ}$ $2002 / 23$.

Municipality of Lausanne. 2002b. Plan directeur du sport: politique municipale en matière de sport [Sports Master Plan: Sports Municipal Policy]. Lausanne: Préavis. №2002/22.

Municipality of Lausanne. 2002c. Bulletin du Conseil communal des séances de l'année civile 2002 [Local Council Reports on the Meetings of 2002]. Lausanne: Bulletin. № 14, 8 Octobre 2002.

Municipality of Lausanne. 2006. Introduction d'une politique de marketing urbain et d'un projet de « city management » en Ville de Lausanne [Introduction of an Urban Marketing Policy and a "City Management" Project for the City of Lausanne]. Lausanne: Préavis. $N^{\circ} 2006 / 51$.

Pinson, J. 2014. "Heritage Sporting Event: An Old Recipe for a New Problem." In Proceedings of the Heritage, Tourism and Hospitality: International Conference 2014, edited by F. Go, M. D. Alvarez and A. Yüksel, 127-138. Istanbul: Boğaziçi University.

Pinson, J., and J.-L. Chappelet. 2014. "Performance de la politique publique «Lausanne, Capitale Olympique»." In Management et évaluation de la performance, un défi pour les organisations sportives, edited by T. Zintz and M. Winand, 67-83. Bruxelles: De Boeck.

Ritchie, J.-R.-B. 1984. "Assessing the Impact of Hallmark Events: Conceptual and Research Issues." Journal of Travel Research 23 (1): 2-11.

Taks, M. 2013. "Social Sustainability of Non-mega Sport Events in a Global World." European Journal for Sport and Society 10: 121-141.

Taks, M., B. C. Green, L. Misener, and L. Chalip. 2014. "Evaluating Sport Development Outcomes: The Case of a Medium-sized International Sport Event." European Sport Management Quarterly 14: 213-237.

Taks, M., L. Chalip, and B. C. Green. 2015. "Impacts and Strategic Outcomes from Non-mega Sport Events for Local Communities.” European Sport Management Quarterly 15 (1): 1-6.

Teigland, J. 1999. "Mega-events and Impacts on Tourism; the Predictions and Realities of the Lillehammer Olympics." Impact Assessment and Project Appraisal 17 (4): 305-317.

Varley, A. 1992. "Barcelona’s Olympic Facelift.” Geographical Magazine 64 (Jul): 20-24.

Vigor, A., M. Mean, and C. Tims, eds. 2004. After the Gold Rush: A Sustainable Olympics for London. London: Institute for Public Policy Research.

Vuignier, R. 2015. "Cross-Border Place Branding: The Case of Geneva Highlighting Multidimensionality of Places and the Potential Role of Politico-Institutional Aspects." In InterRegional Place Branding: Best Practices, Challenges and Solutions, edited by S. Zenker and B. P. Jacobsen, 63-72. Cham: Springer. 
Waller, S., S. Trendafilova, and R. Daniell. 2015. "Did the 2012 World Series Positively Impact the Image of Detroit? Sport as a Transformative Agent in Changing Images of Tourism Destinations." Journal of Sport \& Tourism 19 (1): 79-100. DOI:10.1080/14775085.2015.1017518.

Wamsley, K. B. 2002. "The Global Sport Monopoly: A Synopsis of 20th Century Olympic Politics.” International Journal 57 (3): 395-410.

Whitson, D., and J. Horne. 2006. "Part 2 The Glocal Politics of Sports Mega-events: Underestimated Costs and Overestimated Benefits? Comparing the Outcomes of Sports Mega-events in Canada and Japan.” The Sociological Review 54 (2): 71-89.

Zhang, L., and S. X. Zhao. 2009. "City Branding and the Olympic Effect: A Case Study of Beijing." Cities 26 (5): 245-254.

Ziakas, V., and C. A. Costa. 2011. "Event Portfolio and Multi-purpose Development: Establishing the Conceptual Grounds.” Sport Management Review 14 (4): 409-423. 